\title{
New coffee (Coffea arabica) genotypes derived from Coffea canephora exhibiting high levels of resistance to leaf rust and Ceratocystis canker
}

\author{
Bertha Lucía Castro Caicedo ${ }^{1}$, Hernando A. Cortina Guerrero ${ }^{2}$, Jolanda Roux ${ }^{1}$ \& Michael J. Wingfield $^{1}$ \\ ${ }^{1}$ Department of Microbiology and Plant Pathology, Forestry and Agricultural Biotechnology Institute (FABI), University \\ of Pretoria, Hatfield, Pretoria 0028, South Africa. ${ }^{2}$ National Coffee Research Center (CENICAFE), Chinchiná, Caldas, \\ Colombia
}

Author for correspondence: Bertha Lucía Castro Caicedo, e-mail: Berthal.castro@cafedecolombia.com

\begin{abstract}
The purpose of this study was to evaluate the resistance to coffee leaf rust (CLR) caused by Hemileia vastatrix and to Ceratocystis canker $(\mathrm{Cc})$ in coffee genotypes derived from crosses of Coffea arabica var. Caturra with accessions of $C$. canephora backcrossed to Caturra. Twenty-three $\mathrm{F}_{3} \mathrm{BC}_{1}$ progenies including $C$. arabica var. Caturra and var. Colombia as controls were established in a field experiment. CLR evaluations were made during five years of natural infection, using an incidence rating scale. For $\mathrm{Cc}$, artificial stem inoculations were made with an isolate of Ceratocystis colombiana and the results were assessed after one year. The selection process also included agronomic aspects such as plant height, canopy diameter, number of branch pairs, yield and grain characteristics. Twenty progenies showed $>70 \%$ of rust resistance. Twelve progenies exhibited $>80 \%$ of Cc resistance, while no resistance was observed in either of the controls. Only three progenies performed well for all criteria, including resistance to both pathogens and agronomic characteristics.

Key words: Ceratocystis colombiana, Ceratocystis fimbriata, Hemileia vastatrix, genetic resources, robusta coffee.
\end{abstract}

\section{INTRODUCTION}

Two major diseases that are currently responsible for significant yield reduction in Colombian coffee production are coffee leaf rust (CLR), caused by the obligate pathogen Hemileia vastatrix Berk. \& Broome (Rivillas et al., 2011) and Ceratocystis canker $(\mathrm{Cc})$, caused by the soil-borne fungi Ceratocystis papillata Van Wyk \& Wingf. and $C$. colombiana Van Wyk \& Wingf. (Van Wyk et al., 2010). Of these, CLR is the best known and arguably the most damaging coffee disease in the world, resulting in crop losses of $20-40 \%$ where no control measures are used (Van der Vossen, 2005; Rivillas et al., 2011). Recently, reports from Central American countries suggest up to 80\% defoliation caused by this disease (Cressey, 2013).

At least 49 rust races have been identified in coffee using a set of more than 40 coffee differentials, including the two commercial species cultivated in the world: Coffea arabica $\mathrm{L}$. (tetraploid $2 \mathrm{n}=4 \mathrm{x}=44$ ) and $C$. canephora Pierre: A. Froehner (diploid $2 \mathrm{n}=2 \mathrm{x}=22$ ) (Varzea \& Marques, 2005; Gichuru et al., 2012). The pathogen H. vastatrix has (with various periods of delay), followed the spread of C. arabica around the world. This includes the Americas, where the traditional Typica and Borbón varieties, and their derivatives, are susceptible to race II (genotype v5 v5), the most predominant race in the world (Eskes et al., 1989; Van der Vossen, 2005). In Colombia, where only C. arabica has been cultivated, CLR race II was reported for the first time in 1983 affecting var. Caturra (Leguizamón et. al., 1984). Subsequently, more than 10 different races have been identified (Castillo \& Leguizamón, 1992; Gil \& Ocampo, 1998; Alvarado, 2005; Cristancho et al., 2007). After the severe epidemics reported in Colombia during 2008-2011, with losses above $30 \%$ (Cristancho et al., 2012), molecular studies showed that race II and its derivatives prevail in this country (Rozo et al., 2012).

Several breeding programs have developed durable resistance against CLR, using the dominant major resistance genes (Sh) identified in some Coffea species (Van der Vossen, 2005). Nine dominant genes involved in resistance to $H$. vastatrix have been identified so far (Bettencourt \& Rodriguez, 1988). Genes $\mathrm{S}_{\mathrm{H}} 1, \mathrm{~S}_{\mathrm{H}} 2, \mathrm{~S}_{\mathrm{H}} 4$ are present in non-commercial varieties of $C$. arabica; $\mathrm{S}_{\mathrm{H}} 5$ is present in commercial varieties of $C$. arabica such as Caturra, Typica and Borbón, among others (Bettencourt \& Rodriguez, 1988). Gene $\mathrm{S}_{\mathrm{H}} 3$ appears to come from C. liberica W.Bull.: Hiern. and genes $\mathrm{S}_{\mathrm{H}} 6$ to $\mathrm{S}_{\mathrm{H}} 9$ have been introgressed from C. canephora in some introductions of the Timor Hybrid $(\mathrm{TH})$, which is a self-fertile spontaneous tetraploid $(2 \mathrm{n}=44)$ originating from $C$. arabica and C. canephora. Among these TH introductions are CIFC-1343, CIFC- 832, CIFC2570, and their resistant genes come from some accessions of C. canephora (Bettencourt \& Rodrigues, 1988). Mahe et al. (2007) reported new sources of rust resistance in other 
natural interspecific hybrids from New Caledonia, and more recently, Brito et al. (2010) identified one additional resistance gene to race II of $H$. vastatrix in TH-UFV-42715. Fernandez et al. (2012) suggested potential novel rust resistance genes from genomic studies.

Most coffee breeding programs have used $\mathrm{TH}$ as the main source of CLR resistance (Van der Vossen, 2001). In Colombia, TH accession 1343 has been the source of major resistance genes transferred into the dwarf variety C. arabica var. Caturra (CLR susceptible), which resulted in the resistant varieties Colombia (Castillo \& Moreno, 1988) and Castillo (Alvarado et al., 2005). TH 1343 is also the parent of the Tabi variety, arising from cross between Typica and Borbon (Moreno, 2002). These varieties are currently planted in $\sim 58 \%$ of Colombian coffee growing areas (FEDERACAFE, unpublished).

Despite the success of CLR breeding programs, there is evidence that some improved commercial varieties derived from $\mathrm{TH}$ have lost their resistance due to the possible emergence of new virulent races of the pathogen (Várzea \& Marques, 2005; Prakash et al., 2005; Alvarado, 2005, Gichuru, et al., 2012). Variability in virulence of the pathogen could be due to natural mutation processes, but it could also arise from other mechanisms such as cryptic sex, a hidden sexual reproduction of the pathogen (Carvalho et al., 2011). Therefore breeding programs have focused on efforts to broaden the genetic base of commercial coffee varieties. This especially has been through the exploration of alternative resistant resources, mainly from diploid species such as $C$. canephora or $C$. liberica and the introgression of genes into C. arabica (Varzea \& Marques, 2005; Herrera et al., 2002a, 2002b). Coffea arabica is characterized by its autogamous nature and low genetic diversity, while diploid coffee species such as $C$. canephora are reported as allogamous with considerable variability (Berthaud \& Charrier, 1988; Anthony et al., 2002). This includes resistance to other diseases, such as those caused by nematodes (Bertrand et al., 2001; Noir et al., 2003) and possibly to coffee berry disease (CBD) caused by Colletotrichum kahawae Waller \& Bridges (Gichuru et al., 2006). Hence, the introgression of desired characters from diploid species into cultivars of $C$. arabica has been a priority in coffee breeding (Van der Vossen, 2001).

Ceratocystis canker $(\mathrm{Cc})$, known in most LatinAmerican coffee producing countries as "llaga macana" or "trunk canker" is an important disease of coffee in Colombia (Castro et al., 2003). Fernández (1964) described the symptoms in coffee plants in some provinces of Colombia caused by the soilborne pathogen Ceratocystis fimbriata Ell.\& Halst. Chlorosis, dieback and wilt are the external symptoms in plants that have been affected in their vascular tissues, primarily in the stem, where the dark lesions extend upwards or downwards, girdling the trunk and causing tree death. Currently the disease is found in all the Colombian coffee-growing areas (Marin et al., 2003) and all commercial coffee varieties (C. arabica) planted in this country are susceptible to the disease (Castro et al., 2003). Mechanical injuries (fresh wounds) are the main sources of entry for the pathogen in coffee plants. These wounds arise from farmers stabilizing their boots on the trunks of trees in order to support themselves on the steep slopes where coffee is cultivated, and also from pruning, leading to "llaga macana" (Castro et al., 2003).

Ceratocystis fimbriata sensu lato (s.1.) complex is associated with vascular diseases in a large number of plants in many parts of the world. Webster \& Butler (1967) recognized that C. fimbriata probably represented more than one entity. Baker et al. (2003) hypothesize that local populations of $C$. fimbriata in some Latin American plants have become specialized on different hosts. Studies developed during the last twelve years with isolates from both soil and plants in affected Colombian coffee areas have revealed two phylogenetic lineages (Barnes et al., 2001; Marin et al. 2003). Based on morphological and DNA sequence comparison of isolates from different hosts in Colombia (coffee, cocoa, citrus and native forest), Van Wyk et al. (2010) named the two lineages Ceratocystis colombiana Van Wyk \& Wingf. and C. papillata Van Wyk \&Wingf. Both species are pathogenic, causing death of coffee plants artificially inoculated in their stems (Marin et al., 2003; Van Wyk et al., 2012).

Apparently all C. arabica commercial varieties are susceptible to Ceratocystis canker, however, an exceptional case of resistance has been reported in a line of C. arabica var. Borbón. Such resistance is characterized by the formation of lignified tissues surrounding infection sites and preventing the girdling of plant stems (Fernández, 1964). In the "immune" C. canephora and C. liberica, necrotic lesions do not develop due to rapid wound closure (Echandi \& Fernández, 1961; Izquierdo, 1988). Recently such "immunity" was also recorded in the Colombian National Center of Coffee Research (Cenicafé, Colombia) in some accessions of $C$. canephora and C. liberica in artificial inoculations with C. colombiana and C. papillata (Bertha L. Castro, unpublished).

Selection and breeding for disease resistant/tolerant coffee cultivars remains an ongoing challenge and priority in Colombia. Besides developing rust resistant commercial coffee varieties, it has also been necessary to consider resistance to Ceratocystis canker in these. Using the resistant Borbón line, Castro \& Cortina (2009) developed Caturra-like genotypes with resistance to "llaga macana," but these were susceptible to rust. Hence, development of varieties resistant to both rust and $\mathrm{Cc}$ is necessary. One approach would be to develop promising genotypes from gene introgression into $C$. arabica by the way of triploid hybrids, through crossing of $C$. arabica $\mathrm{x} C$. canephora (Orozco, 1976; Alvarado \& Cortina, 1997; Herrera et al., 2002a, 2002b). Following this strategy, researchers at Cenicafé crossed tetraploid $C$. arabica var. Caturra with accessions of diploid C. canephora, generating triploids backcrossed $(\mathrm{BC})$ to Caturra. Based on rust resistant 
tetraploid $\mathrm{F}_{2} \mathrm{BC}_{1}$ genotypes, the aim of this study was to select $\mathrm{F}_{3} \mathrm{BC}_{1}$ progenies simultaneously resistant to both CLR and Ceratocystis canker. Furthermore, the process of selection included desirable agronomic characteristics and bean attributes that will be useful for future commercial varieties.

\section{MATERIAL AND METHODS}

\section{Genotypes and field experiment}

Twenty-three $\mathrm{F}_{3}$ progenies produced by crossing $C$. arabica var. Caturra with three accessions of $C$. canephora and backcrossed with var. Caturra $\left(\mathrm{F}_{3} \mathrm{BC}_{1}\right)$ were included in the study. The different parental accessions were selected from Cenicafé's germplasm collection (Chinchiná, Colombia). These tetraploid interspecific hybrids, labeled as MEG 639, were generated by crossing the C. arabica var. Caturra as female parent (susceptible to both CLR and Cc) with accessions of C. canephora (BP.358-EA.93; BP.358EA.239 and BP.46-EA.131) known to be CLR resistant, and backcrossed to Caturra. Two controls, C. arabica var. Colombia (CLR resistant, but Cc susceptible) and var. Caturra (susceptible to both pathogens) were included.

Field plots were established at Cenicafé Central Experiment Station $\left(04^{\circ} 58^{\prime} \mathrm{NL}, 7^{\circ} 39^{\prime} \mathrm{W}, 1381 \mathrm{~m}\right)$ in 1998. The site has an annual average precipitation of 2556 $\mathrm{mm}$, sunshine of 1816 hours/year, relative humidity of $78 \%$ and a mean temperature of $20.8^{\circ} \mathrm{C}$ (Cenicafé, 2008). Trees were planted in a square lattice ( 5 x 5) and two replicates were used per treatment in the experimental design. The experimental unit was a line of 10 plants with distance of $1.6 \times 1.0 \mathrm{~m}$ between plants and $2.5 \mathrm{~m}$ between blocks. Standard agronomic management was applied.

\section{Coffee leaf rust evaluation}

Incidence of $H$. vastatrix infection was evaluated from January 2000 to August 2005, during periods of heavy rust outbreaks as defined by Sierra et al. (1991). The rating scale of Eskes \& Braghini (1981) was used for plant evaluation. This scale grades the whole plant as a unit of observation on a visual scale ( 0 to 9 ), where $0=$ absence of sporulating lesions; 1 = presence of one diseased branch; 2 to $8=$ gradual increase in number of diseased branches with sporulating lesions; and $9=$ maximum disease incidence. At each evaluation, the number of plants with rust was scored and grouped into three categories: uninfected plants (grade 0 ); plants with a low level, considered resistant (graded 1 to 4) and plants with high level of infection, as susceptible (graded 5 to 9). The maximum grade of each tree was recorded along with the frequency of plants of each grade, according to the criteria of Alvarado \& Cortina (1997).

\section{Ceratocystis canker evaluation}

When the plants reached an age of seven years, they were inoculated with isolate CMW 34925 of Ceratocystis colombiana (GenBank accession number of ITS-rDNA sequence KF300545) (Van Wyk et al., 2010), previously identified as highly virulent by Castro \& Cortina (2009). The inoculum was prepared as previously described by Marin et al. (2003). Drops of $70 \mu \mathrm{L}$ containing approximately $3.0 \mathrm{x}$ $10^{4}$ ascospores $/ \mathrm{mL}$, were inoculated into inverted U-shaped wounds, approximately $2.0 \mathrm{~cm}$ in diameter, made on the stems at $\sim 1.40 \mathrm{~m}$ above soil line. The spore suspension was inserted under the bark and sealed with parafilm.

Fifteen days after inoculation, the parafilm was removed and pathogen colonization was verified. Red paint was applied to the trunks below the site of inoculation to further identify plants and to aid in later assessments. One year after inoculation, the size of the lesions under the stem bark was determined. Three measurements were made for each plant, including stem circumference (SC), width of necrotic lesion (WNL) and lesion length (LL). The width of stem affected (WSA) by the necrotic lesion was expressed as percentage of the stem circumference (SC) girdled (WNL/SC x 100).

\section{Evaluation of agronomic characteristics}

All plants were evaluated for plant height $(\mathrm{cm})$, canopy diameter $(\mathrm{cm})$ and number of branch pairs at 24 months of age. Yield data per plant were also recorded from 2001 to 2005 in $\mathrm{kg}$ of fresh berries per tree. The percentage of bean defects such as empty beans in ripe coffee fruits and defects of dry parchment beans such as "peaberry" ("caracol") and "triangle" were evaluated in two peaks of yield in 2001 and 2002. For empty beans, the floating method was used. The size of dry beans (Supreme type) was determined as the percentage of husked beans (green coffee) retained by a 17/64 inches mesh. The assessment of these bean characteristics was made according to the methods of Castillo \& Moreno (1988) and Moreno and Alvarado (2000), as well as the coffee quality standards (FEDERACAFE, 1988).

\section{Data analysis and selection of promising genotypes}

For CLR, a frequency distribution per progeny was developed for each assessment and the maximum rating was considered with these results expressed as percentage of plants affected. Data were grouped based on a severity scale from 0 (uninfected plants), grade 1 to 4 , and grade 5 to 9 . Progeny with $\geq 70 \%$ of plants graded $0-4$ on the CLR scale were selected as resistant because at this level there is no effect on productivity (Eskes \& Braghini, 1981; Alvarado \& Cortina, 1997).

To analyze the Cc data, the mean values of the measurements for each coffee genotype were calculated and analysis of variance (ANOVA) was performed for the WSA and LL data at a significance level of $\mathrm{P}=0.05$. Tukey's test $(\mathrm{P}=0.05)$ was used to compare the results for different progenies. All analyses were done using the SAS statistical program (SAS Statistical Software, 2010). Resistant genotypes were selected as those where $>80 \%$ of plants had WSA values lower than 50\% and with lesions 
smaller than those of the susceptible controls, following the method previously used by Castro \& Cortina (2009).

For agronomic characteristics, ANOVA was performed for plant height, canopy diameter and number of branch pairs as well as grain characteristics and annual yield over five years. The yield data were taken from harvests obtained over five years and the average ( $\mathrm{kg}$ of fresh berries/ tree/year) was transformed to kg of dry parchment coffee/ plant/year, using the conversion factors of Montilla et al. (2008). Where statistical differences were found among the 23 progenies tested, Dunnett's test $(\mathrm{P}=0.05)$ was used to compare the results with those for var. Caturra. Average agronomic characteristics equal to or better than those of the controls were the criteria used to select promising plants for future use.

\section{RESULTS AND DISCUSSION}

\section{Coffee leaf rust evaluation}

On the basis of 12 evaluations from 2000 to 2005 , clear differences among progenies, as well as between the progenies and the two control varieties, were found (Figure 1). The var. Caturra was the most susceptible of all genotypes tested, with all plants scoring between 5 and 9 on the rating scale. In contrast, progenies MEG639-410, MEG639-475, MEG639-705 and MEG639-708 were the most resistant, with $100 \%$ of plants graded 0 to 4 on the disease assessment scale. Eighteen progenies had greater than $70 \%$ of the plants graded 1 to 4 , and these were also considered resistant.

Since 1983, when CLR (Race II) was detected in Colombia (Leguizamón et al., 1984), there has been a gradual increase in disease severity, depending on weather conditions (Sierra et al., 1991; Rivillas et al., 2011, Rozo et al., 2012). During the course of the current project, the highest CLR incidence $(>60 \%)$ was found on var. Caturra in 2003 and 2005. In contrast, very low levels $(<30 \%)$ of rust were observed in 2004. This behavior is related to climatic conditions as well plant vigor and size of the harvest, amongst other factors (Kushalappa \& Eskes, 1989; Costa et al., 2006).

Overall, results of this study indicate that the selection of CLR resistant progeny made in earlier generations $\left(\mathrm{F}_{2} \mathrm{BC}_{1}\right)$ assured an $87 \%$ level of resistance in the presently used progenies $\left(\mathrm{F}_{3} \mathrm{BC}_{1}\right)$. The resistance found in var. Colombia indicates that, while the resistance genes in this variety come from the $C$. canephora through the TH/1343 (Castillo \& Moreno, 1987), the rust resistant genes in the $\mathrm{F}_{3}$ progenies studied are different from the ones present in the varieties Colombia, Tabi and Castillo, whose resistance introgressed from the unique $\mathrm{TH}$. This is evident in our study, because at least seven progenies had some plants totally resistant, while all progeny of var. Colombia were infected, although at a low level. This possibility was also raised by Mahe et al. (2007), who studied the genetic diversity and rust resistance in natural interspecific hybrids between C. arabica x C. canephora from New Caledonia (HNC) and found resistance to all rust races in some progeny. Based on molecular data, they suggested a high level of genetic diversity of $C$. canephora progenitors at the origin of HNCs. For Colombian coffee, this new source of resistance genes may have important consequences. After the last severe rust outbreak of 2008-2011 (Cristancho et al., 2012), the susceptible var. Caturra has been replaced by commercial resistant multiline varieties derived from $\mathrm{TH} / 1343$. The increasing area planted with these lines may intensify the selection pressure on the pathogen, favoring the emergence of compatible races and thus threatening resistance durability. Therefore, the incorporation of new genotypes with different rust resistant genes, such as those selected in this study, into current breeding programs should increase the stability and durability of CLR resistance.

\section{Ceratocystis canker evaluation}

There was variability in the resistance reactions against $\mathrm{Cc}$ in the genotypes tested. Twelve progenies were statistically different to the susceptible control varieties in WSA, with $<50 \%$ of the stem circumference affected by lesions (Figure 2). Eight of these progenies were also significantly different from the controls in LL (Figure 3). Progenies MEG639-708, MEG639-617, MEG639-841, MEG639-620, MEG639-601, MEG639-842, MEG639-704, MEG639-602, MEG639-609, MEG639-475, MEG639-771 and MEG639-705 were the most resistant to C. colombiana infection, compared with susceptible control varieties, which were killed by the pathogen. Progenies MEG 639841, MEG 639-617 and MEG 639-708 exhibited the smallest lesions, suggesting a possible form of "immunity". This last resistant reaction was also noticed by Echandi \& Fernández (1961) in inoculations with C. fimbriata s.l on $C$. canephora and $C$. liberica in Guatemala, and by Izquierdo (1988) in Cuba on C. canephora.

Among the progenies with resistance reactions, strong callus formation was observed surrounding the necrotic lesions (Figure 4A and 4B) with small amounts of discoloured tissue in the underlying wood (Figure 4C). In contrast, wood discoloration spread either upwards or downwards, and there was an absence of an obvious defense response in susceptible controls or susceptible progenies (Figure 4D). Our results showed clear evidence of resistance to Ceratocystis infection, probably conferred by the parental C. canephora through the hybridization, and the resistance persisted after backcrossing to the susceptible var. Caturra. This form of resistance is mentioned in other studies (Echandi \& Fernández, 1961; Izquierdo, 1988); as well as in recent studies performed at Cenicafé (Castro unpublished) in inoculations with $C$. colombiana and $C$. papillata on the diploid coffee species $C$. canephora and C. liberica. The progenies selected in the present study may give rise to new resistant genes and may be valuable as efforts are made to reduce the damage caused by Ceratocystis spp. in Colombia. 


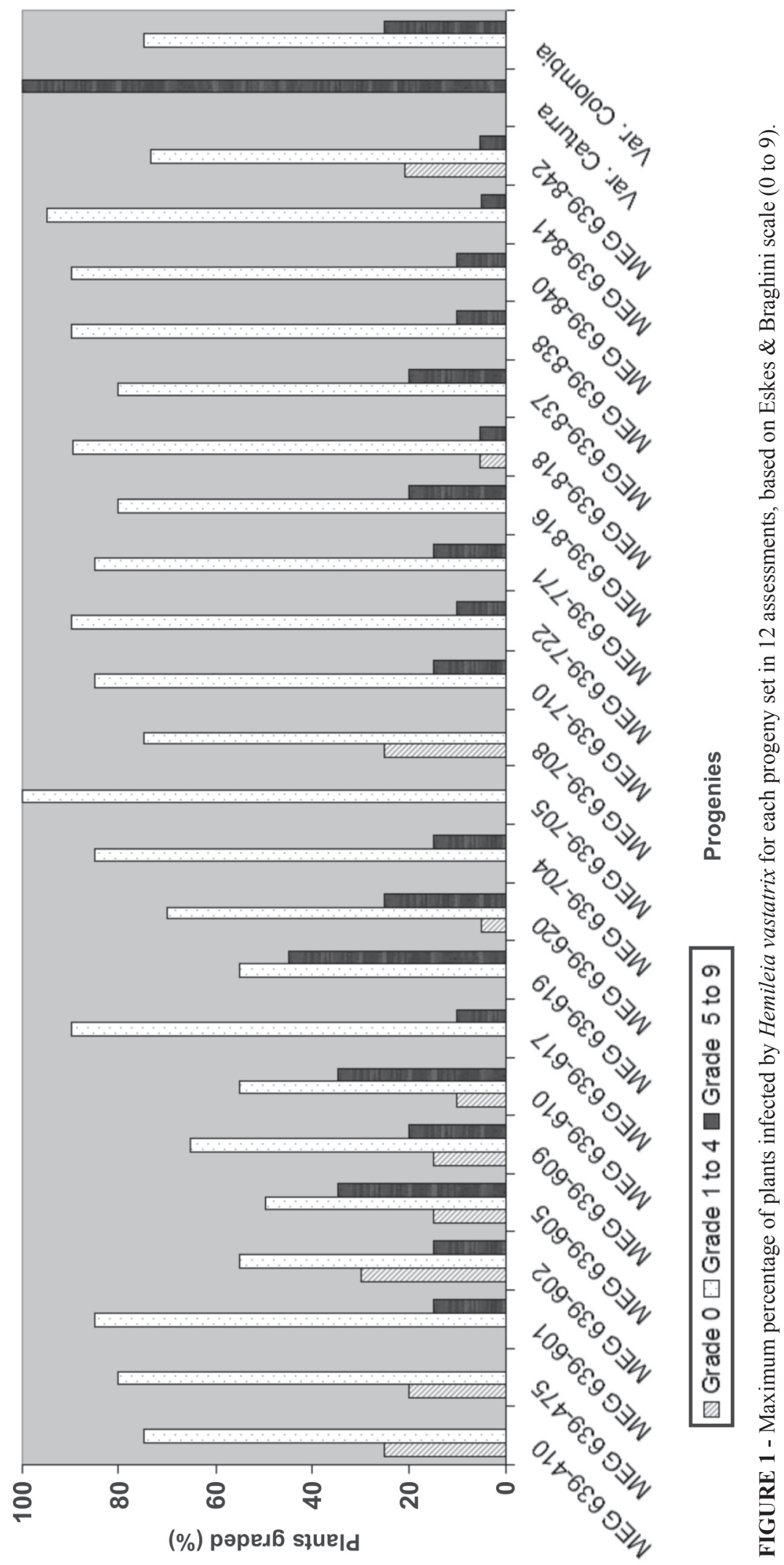


B.L.C. Caicedo et al.
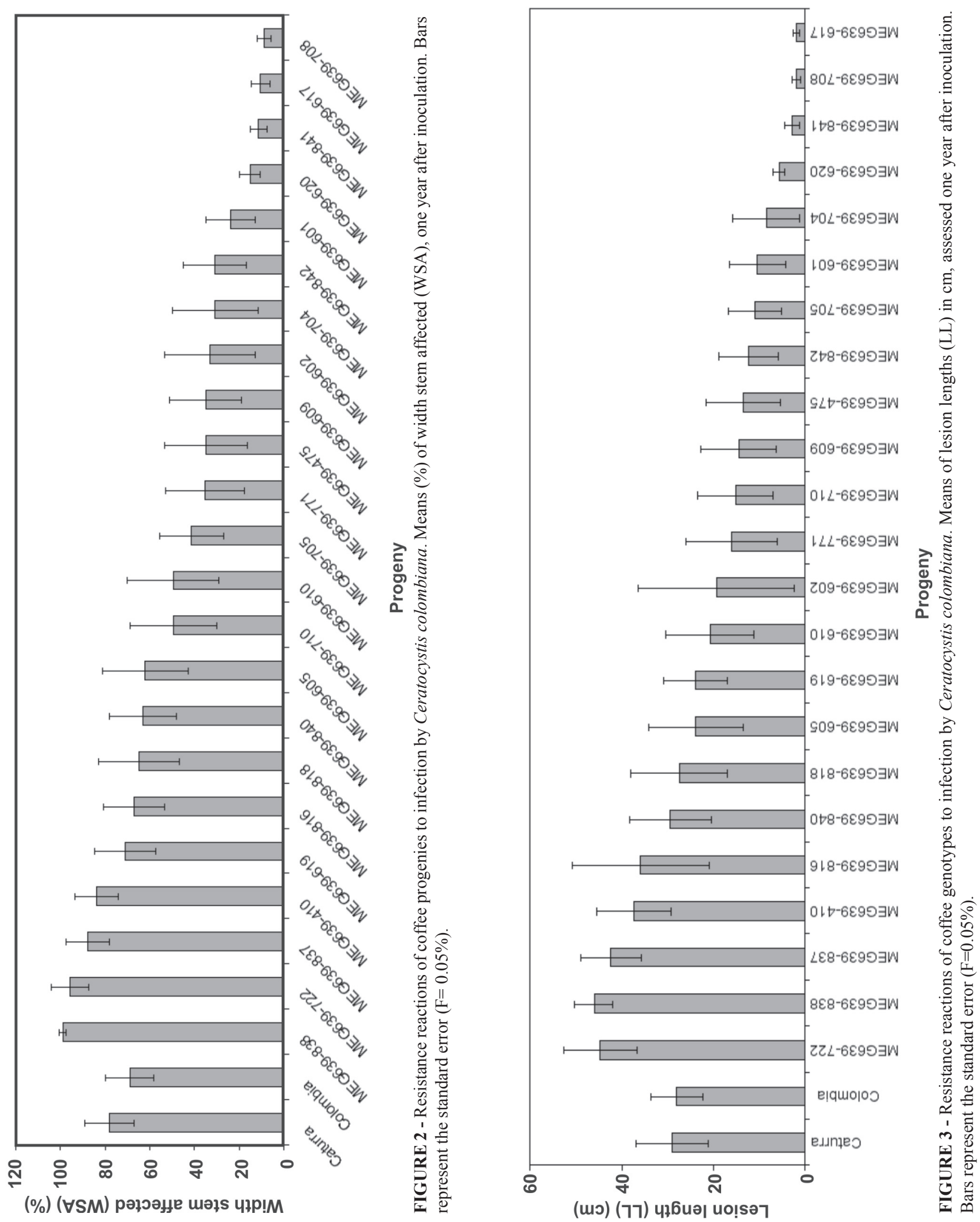

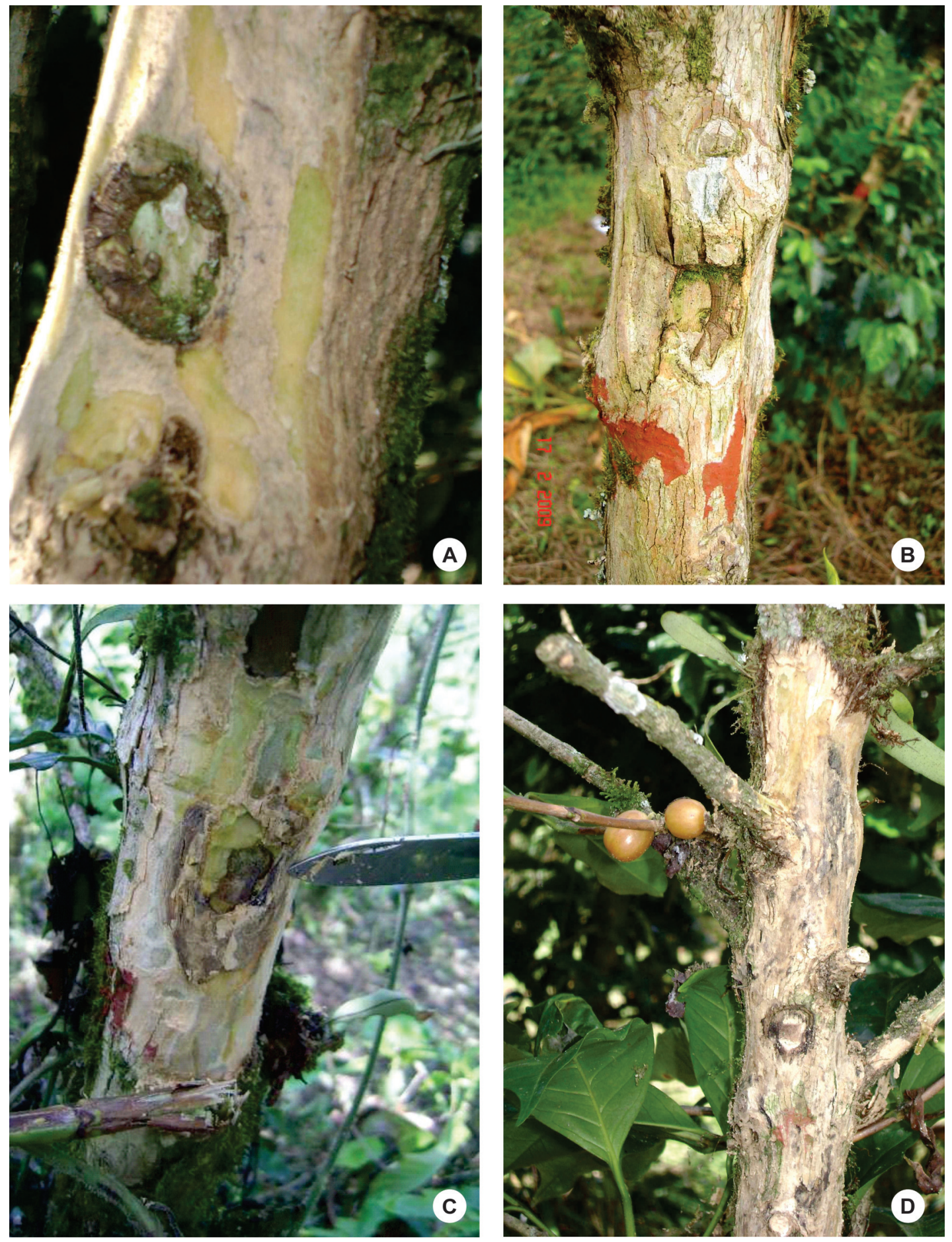

FIGURE 4 - Resistance reaction displayed by some progenies with strong callus formation (A, B) and reduced lesion area in the underlying wood $(\mathbf{C})$, compared with wood discolouration $(\mathbf{D})$ in controls and susceptible progenies $\mathrm{F}_{3} \mathrm{BC}_{1}$ derived from interspecific hybrids (Coffea canephora $x$ C. arabica) one year after inoculation of Ceratocystis colombiana.

\section{Evaluation of agronomic characteristics}

The average plant height ranged from 131 to 161 $\mathrm{cm}$ in the progenies, while var. Caturra and var Colombia were an average height of $133 \mathrm{~cm}$ and $144 \mathrm{~cm}$, respectively. Statistical differences $(\mathrm{P}<0.0001)$ were observed only for progenies MEG639-410 and MEG639-602, which were significantly taller than var. Caturra. No differences were noticed in the number of branches nor in canopy diameter for either the progenies or the controls. These phenotypic attributes are commercially accepted by Colombian coffee 
growers and also mentioned by Castillo \& Moreno (1988) and Alvarado \& Cortina (1997).

Variable bean characteristics were observed in the progenies (Table 1). Dunnett's test showed that ten of these had a higher percentage of empty beans than var. Caturra $(3.9 \%)$ and var. Colombia $(5.9 \%)$, while the rest of the progenies had acceptable ranges of bean production as defined by Castillo \& Moreno (1988). Similarly, the progenies had higher peaberry values (average, 14.6\%) than the two controls (average 8.2\%). Dunnett's test showed that 12 progenies had different values to those of var. Caturra $(8.4 \%)$ and var. Colombia $(9.6 \%)$. The frequency of triangle beans was low, with an average of $4 \%$, which is within the acceptable range according to Castillo \& Moreno (1987) and no differences were observed for this trait.

The average Supreme bean size (percent beans retained by a 17/64 inch screen) in the progenies was $61.0 \%$, better than var. Caturra $(41.0 \%)$, but lower than var. Colombia (66.0\%). Dunnet's test showed that 14 progenies and var. Colombia had larger beans than var. Caturra. Progenies MEG639-771 (45.0 \%) and MEG 639-818 had bean sizes that were much lower $(37.0 \%)$ than expected (Table 1), according to the criteria established by Moreno \& Alvarado (2000) for commercial varieties.

For average yield calculations (Table 1), differences $(\mathrm{P}<0.0001)$ and Dunnet's test showed that progenies MEG639-602, MEG639-705, MEG639-722, MEG639-771 and MEG639-841 were more productive than var. Caturra. There were no progenies statistically less productive than the controls. Thus progenies had variable yield and bean attributes, similar to what has been observed by other studies (Alvarado \& Cortina, 1997). However, attributes such as bean size were close to the Colombian commercial varieties (Moreno \& Alvarado, 2000).

Based on their resistance to rust and Ceratocystis canker, as well as on their most important agronomic characteristics (yield and bean size), three progenies (MEG 639- 601; MEG 639- 617 and MEG 639-704) were selected for future breeding development. This study has shown that it is possible to transfer desirable genes for resistance to the most important coffee pathogens to new genotypes. These genotypes will be valuable as new sources of resistance to these pathogens in the future.

TABLE 1 - Bean characteristics and yield (kg of dry parchment coffee/plant/year) for each progeny

\begin{tabular}{|c|c|c|c|c|c|}
\hline \multirow[t]{2}{*}{ Progeny nr. } & \multicolumn{3}{|c|}{ Bean defects $(\%)$} & \multirow{2}{*}{$\begin{array}{c}\text { Bean size } \\
\text { supreme }^{\mathrm{d}}(\%) \\
(\text { Mean } \pm \text { SD) }\end{array}$} & \multirow{2}{*}{$\begin{array}{l}\text { Yield }(\mathrm{Kg}) \\
(\text { Mean } \pm \text { SD) }\end{array}$} \\
\hline & $\begin{array}{l}\text { Empty beans }^{\mathrm{a}} \\
(\text { Mean } \pm \mathrm{SD})\end{array}$ & $\begin{array}{c}\text { Peaberry }^{b} \\
(\text { Mean } \pm \text { SD) }\end{array}$ & $\begin{array}{c}\text { Triangle }^{c} \\
(\text { Mean } \pm \text { SD) }\end{array}$ & & \\
\hline MEG 639.410 & $5.1 \pm 1.4$ & $8.8 \pm 2.0$ & $5.8 \pm 2.3$ & $75.0 \pm 3.8^{*}$ & $3.0 \pm 0.9$ \\
\hline MEG 639.475 & $7.8 \pm 2.9$ & $17.1 \pm 4.1^{*}$ & $0.2 \pm 0.2$ & $53.5 \pm 14.3$ & $3.2 \pm 1.2$ \\
\hline MEG 639.601 & $6.6 \pm 2.9$ & $13.3 \pm 4.0$ & $3.2 \pm 1.6$ & $64.9 \pm 4.3 *$ & $3.2 \pm 1.4$ \\
\hline MEG 639.602 & $10.5 \pm 4.1 *$ & $20.7 \pm 8.4^{*}$ & $2.9 \pm 2.1$ & $54.6 \pm 2.4$ & $3.6 \pm 1.2 *$ \\
\hline MEG 639.605 & $13.5 \pm 5.8 *$ & $27.0 \pm 13.3 *$ & $4.3 \pm 2.3$ & $58.7 \pm 4.8 *$ & $3.0 \pm 1.1$ \\
\hline MEG 639.609 & $7.5 \pm 3.0$ & $12.6 \pm 2.9$ & $3.5 \pm 1.3$ & $50.5 \pm 16.4$ & $2.7 \pm 1.1$ \\
\hline MEG 639.610 & $6.4 \pm 1.6$ & $9.7 \pm 2.4$ & $6.7 \pm 2.2$ & $60.0 \pm 8.8 *$ & $3.1 \pm 1.0$ \\
\hline MEG 639.617 & $8.6 \pm 3.2$ & $10.7 \pm 5.5$ & $8.0 \pm 1.8$ & $70.3 \pm 6.2^{*}$ & $3.1 \pm 0.6$ \\
\hline MEG 639.619 & $7.5 \pm 3.8$ & $11.0 \pm 1.4$ & $8.7 \pm 2.4$ & $55.6 \pm 7.5$ & $2.7 \pm 0.9$ \\
\hline MEG 639.620 & $11.1 \pm 4.6^{*}$ & $18.7 \pm 10.6^{*}$ & $1.9 \pm 1.1$ & $63.3 \pm 11.9^{*}$ & $3.1 \pm 1.2$ \\
\hline MEG 639.704 & $5.1 \pm 1.7$ & $12.4 \pm 4.8$ & $4.9 \pm 2.6$ & $66.6 \pm 11.3^{*}$ & $3.1 \pm 0.9$ \\
\hline MEG 639.705 & $12.3 \pm 7.7 *$ & $24.7 \pm 9.2^{*}$ & $2.3 \pm 0.8$ & $64.5 \pm 8.5^{*}$ & $4.0 \pm 1.1^{*}$ \\
\hline MEG 639.708 & $7.2 \pm 3.0$ & $9.5 \pm 1.9$ & $5.9 \pm 3.1$ & $55.7 \pm 9.2$ & $3.1 \pm 1.0$ \\
\hline MEG 639.710 & $9.8 \pm 4.0^{*}$ & $15.2 \pm 7.9^{*}$ & $2.9 \pm 1.3$ & $61.8 \pm 10.4 *$ & $2.6 \pm 1.1$ \\
\hline MEG 639.722 & $5.1 \pm 1.3$ & $8.1 \pm 1.9$ & $1.8 \pm 0.6$ & $70.6 \pm 7.4^{*}$ & $4.2 \pm 0.8^{*}$ \\
\hline MEG 639.771 & $9.9 \pm 8.5^{*}$ & $15.7 \pm 4.4^{*}$ & $7.0 \pm 3.9$ & $44.9 \pm 19.2$ & $3.5 \pm 1.4^{*}$ \\
\hline MEG 639.816 & $9.5 \pm 8.0^{*}$ & $18.2 \pm 5.3 *$ & $0.9 \pm 0.6$ & $47.8 \pm 16.9$ & $3.2 \pm 1.0$ \\
\hline MEG 639.818 & $9.3 \pm 4.5$ & $20.8 \pm 1.20 *$ & $0.5 \pm 0.4$ & $37.4 \pm 19.6$ & $3.3 \pm 1.4$ \\
\hline MEG 639.837 & $9.1 \pm 3.3^{*}$ & $27.4 \pm 11.4^{*}$ & $4.1 \pm 2.3$ & $62.2 \pm 13.8^{*}$ & $3.1 \pm 1.2$ \\
\hline MEG 639.840 & $6.1 \pm 2.8$ & $14.1 \pm 3.6$ & $0.8 \pm 0.6$ & $74.9 \pm 10.1 *$ & $3.1 \pm 1.0$ \\
\hline MEG 639.838 & $6.3 \pm 3.6$ & $16.3 \pm 6.0 *$ & $4.1 \pm 2.6$ & $57.9 \pm 13.6$ & $2.9 \pm 1.2$ \\
\hline MEG 639.841 & $11.4 \pm 10.2^{*}$ & $16.4 \pm 3.5^{*}$ & $1.1 \pm 0.7$ & $70.3 \pm 8.7^{*}$ & $3.5 \pm 1.1 *$ \\
\hline MEG 639.842 & $4.7 \pm 8.2 *$ & $12.3 \pm 2.6$ & $1.0 \pm 0.6$ & $73.8 \pm 8.3^{*}$ & $3.1 \pm 1.1$ \\
\hline Var. Caturra & $3.9 \pm 1.0$ & $8.4 \pm 2.8$ & $5.8 \pm 1.2$ & $41.0 \pm 7.5$ & $2.4 \pm 0.8$ \\
\hline Var. Colombia & $5.9 \pm 2.2$ & $9.6 \pm 2.6$ & $2.3 \pm 1.3$ & $66.0 \pm 12.6^{*}$ & $3.2 \pm 1.0$ \\
\hline
\end{tabular}

${ }^{a}$ Empty beans: Average percent of 100 ripe coffee fruits floating in three samples of two harvest peaks

${ }^{b}$ Peaberry: Average percent in three samples of 400 dry parchment beans of two harvest peaks.

c Triangle: Average percent in three samples of 400 dry parchment beans of two harvest peaks

d Supreme: Average percent of three samples of $100 \mathrm{~g}$ of husked beans (green coffee) retained by a 17/64 inch screen.

*Statistical differences (0.05) according to Dunnett's test are indicated for each character. 
New coffee (Coffea arabica L.) genotypes derived from Coffea canephora exhibiting high levels...

\section{ACKNOWLEDGEMENTS}

We thank Dr. Alvaro Gaitán, plant pathologist of Cenicafé, for his valuable advice and for reviewing an earlier version of the manuscript. We also thank the Plant Breeding group at the Colombian National Center of Coffee Research (CENICAFE) for maintaining the field experiments, and acknowledge the University of Pretoria for providing partial financial support for this work.

\section{REFERENCES}

Alvarado AG (2005) Evolution of Hemileia vastatrix virulence in Colombia. In: Zambolim L, Zambolim E, Varzea V (Eds.) Durable Resistance to Coffee Leaf Rust. Viçosa MG, Brazil. Editora UFV. pp. 99-115.

Alvarado AG, Cortina HA (1997) Comportamiento agronómico de progenies de híbridos triploides de C. arabica var Caturra $\mathrm{X}$ (Caturra $x$ C. canephora). Cenicafe 48:73-91.

Alvarado AG, Posada HE, Cortina HA (2005) La variedad Castillo: Una variedad de café Coffea arabica L. con elevada productividad y amplia resistencia a enfermedades. Fitotecnia Colombiana 8:121.

Anthony MC, Combes C, Astorga B, Graziosi G, Lashermes P (2002) The origin of cultivated Coffea arabica L. varieties revealed by AFLP and SSR markers. Theoretical and Applied Genetics 104:890-900.

Baker CJ, Harrington CT, Krauss U, Alfenas AC (2003) Genetic variability and host specialization in the Latin America clade of Ceratocystis fimbriata. Phytopathology 93:1274-1284.

Barnes I, Gaur A, Burges T, Roux J, Wingfield BD, Wingfield MJ (2001) Microsatellite markers reflects intra-specific relationships between isolates of the vascular wilt pathogen, Ceratocystis fimbriata. Molecular Plant Pathology 2:319-325.

Berthaud J, Charrier A (1988) Genetic resources of coffee. In: Clarke RJ, Macrae R (Eds.) Coffee: Agronomy, vol 4. London UK. Elsevier Applied Science. pp. 1-42.

Bertrand B, Anthony F, Lashermes P (2001) Breeding for resistance to Meloidogyne exigua of Coffea arabica by introgression of resistance genes of $C$. canephora. Plant Pathology 50:637-643

Bettencourt AJ, Rodrigues CJ (1988) Principles and practices of coffee breeding for resistance to rust and other diseases. In: Clarke SJ, Macrae R (Eds.) Coffee: Agronomy, vol 4. London UK. Elseiver Applied Science. pp. 199-234.

Brito GG, Teixeira E, Gallina AP, Zambolim EM, Zambolim L, Diola V, Loureiro ME (2010) Inheritance of the coffee leaf rust resistance and identification of AFLP markers linked to the resistance gene. Euphytica 173:255-264.

Carvalho CR, Fernandes RC, Carvalho GMA, Barreto RW, Evans HC (2011) Cryptosexuality and the genetic diversity paradox in coffee rust, Hemileia vastatrix. PLoS ONE 6:e26387.

Castillo ZJ, Moreno LG (1988) La Variedad Colombia: Selección de un cultivar compuesto resistente a la roya del cafeto. Chinchiná Colombia. Cenicafé.

Castillo ZJ, Leguizamón CJE (1992) Virulencia de Hemileia vastatrix determinada por medio de plantas diferenciales de café en Colombia. Cenicafé 43:114-124.

Castro BL, Duque H, Montoya EC (2003) Pérdidas económicas ocasionadas por la llaga macana del cafeto. Cenicafé 54:63-76.

Castro BL, Cortina HA (2009) Evaluación de resistencia a Ceratocystis fimbriata Ell. Hals Hunt. en progenies $\mathrm{F}_{5}$ de café Bourbón resistente x Caturra. Cenicafé 60:115-125.

Centro Nacional de Investigaciones de Café - Cenicafé (2008) Anuario Meteorológico cafetero (CD-ROM). Chinchiná Colombia. Cenicafé.

Costa M, Zambolim L, Rodrigues FA (2006) Efeito de níveis de desbaste de frutos do cafeeiro na incidencia da ferrugem, no teor de nutrientes, carbohidrateos e azucares redutores. Fitopatologia Brasileira 31:564-571.

Cressey D (2013) Coffee rust regains foothold. Nature 493:1-2.

Cristancho AMA, Escobar OC, Ocampo MJD (2007) Evolución de razas de Hemileia vastatrix en Colombia. Cenicafé 58:340-359.

Cristancho M, Rozo, Y, Escobar C, Rivillas CA, Gaitán AL (2012) Outbreak of coffee leaf rust (Hemileia vastatrix) in Colombia. New Disease Reports 25: 19.

Echandi E, Fernández CE (1961) Relation between chlorogenic acid contents and resistance to coffee canker incited by Ceratocystis fimbriata. Phytopathology 52:544-546.

Eskes AB (1989) Resistance. In: Kushalappa AC, Eskes AB (Eds.) Coffee Rust: Epidemiology, Resistance and Management. Boca Raton FL, USA. CRC Press. pp. 171-277.

Eskes AB, Braghini M (1981) Métodos de evaluación de la resistencia contra la roya del cafeto (Hemileia vastatrix Berk. Et Br.). Boletin Fitosanitario FAO 29:56-66.

Federación Nacional de Cafeteros de Colombia (FEDERACAFE) (1988) Normas sobre calidad del café. Bogotá Colombia.

Fernández BO (1964) Patogenicidad de Ceratocystis fimbriata y posible resistencia en café var. Borbón. Cenicafé 15:3-17.

Fernandez D, Tisserant E, Talhinhas P, Azinheira H, Vieira A, Petitot AS, Loureiro A, Poulain A, Da Silva C, Silva MDC, Duplessis S (2012) 454-pyrosequencing of Coffea arabica leaves infected by the rust fungus Hemileia vastatrix reveals in plantaexpressed pathogen-secreted proteins and plant functions in a late compatible plant-rust interaction. Molecular Plant Pathology $13: 17-37$.

Gichuru EK, Agwanda CO, Combes MC, Mutitu EW, Ngugi ECK, Bertrand B, Lashermes P (2008) Identification of molecular markers linked to a gene conferring resistance to coffee berry disease (Colletotrichum kahawae) in Coffea arabica. Plant Pathology 57: 1117-1124.

Gichuru EK, Ithiru JM, Silva MC, Pereira AP, Varzea VMP (2012) Additional physiological races of coffee leaf rust (Hemileia vastatrix) identified in Kenya. Tropical Plant Pathology 37:424427.

Gil VLF, Ocampo MJD (1998) Identificación de la raza XXII de Hemileia vastatrix Berl \&Br. en Colombia. Cenicafé 49:340-344.

Herrera JC, Combes MC, Cortina GH, Alvarado AG, Lashermes P (2002a) Gene introgression into Coffea arabica by way of triploid hybrids (C. arabica $x$ C. canephora). Heredity 89:488-494.

Herrera JC, Combes MC, Anthony F, Charrier A, Lashermes P 
(2002b) Introgression into the allotetraploid coffee (Coffea arabica L.): Segregation and recombination of the $C$. canephora genome in the tetraploid interspecific hybrid (C. arabica $x$ C. canephora). Theoretical and Applied Genetics 104:661-668.

Izquierdo JE (1988) Comportamiento de genotipos de cafetos ante Ceratocystis fimbriata. Ciencia y Técnica en la Agricultura. Café y Cacao 10:53-59.

Kushalappa AC, Eskes AB (1989) Coffee Rust: Epidemiology, Resistance, and Management. Boca Raton FL, USA. CRC Press.

Leguizamón JE, Baeza C, Fernández O, Moreno LG, Castillo ZJ, Orozco FJ (1984) Identificación de la Raza II de Hemileia vastatrix Berk \& Ber. en Colombia. Cenicafe 35:26-28.

Mahe L, Varzea VMP, Le Pierres D, Combes MC, Lashermes P (2007) A new source of resistance against coffee leaf rust from New Caledonian natural interspecific hybrids between Coffea arabica and Coffea canephora. Plant Breeding 126:638-641.

Marin M, Castro BL, Gaitán A, Preisig O, Wingfield BD, Wingfield MJ (2003) Relationships of Ceratocystis fimbriata isolates from Colombian coffee-growing regions based no molecular data and pathogenicity. Journal of Phytopathology 151:395-405.

Montilla J, Arcila J, Aristizabal M, Montoya EC, Puerta GI, Oliveros CE, Cadena G (2008) Propiedades físicas y factores de conversión del café en el proceso de beneficio. Cenicafé Avances Técnicos 370:1-8.

Moreno LG (2002) Tabi: variedad de café de porte alto con resistencia a roya. Cenicafé Avances Técnicos 300:1-8.

Moreno LG, Alvarado AG (2000) La Variedad Colombia: Veinte años de adopción y comportamiento frente a nuevas razas de la roya del cafeto. Boletín Técnico Cenicafé 22:1-32.

Noir S, Anthony F, Bertrand B, Combes MC, Lashermes P (2003) Identification of major gene (Mex-1) from Coffea canephora conferring resistance to Meloidogyne exigua in Coffea arabica. Plant Pathology 52:97-103.

Orozco FJ (1976) Utilización del híbrido triploide de C. arabica $\mathrm{x}$ C. canephora en cruzamientos interespecificos. Cenicafé 27: 143157.
Prakash NS, Ganesh D, Bath SS (2005) Population dynamics of coffee leaf rust (Hemileia vastatrix Berk \&Br.) and recent advances in rust research in India. In: Zambolim L, Zambolim EM, Varzea VM (Eds.) Durable Resistance to Coffee Leaf Rust. Viçosa MG, Brazil. Editora UFV. pp. 411-442.

Rivillas CA, Serna CA, Cristancho MA, Gaitán A (2011) La roya del cafeto en Colombia: Impacto, Manejo y Costos de Control. Cenicafé 36:1-51.

Rozo Y, Escobar C, Gaitan A, Cristancho M (2012) Aggressiveness and genetic diversity of Hemileia vastatrix during an epidemic in Colombia. Journal of Phytopathology 160:732-740.

SAS Statistical software (2010) SAS/STAT Users's Guide, Version 9.2. Cary NC, USA. SAS Institute Inc.

Sierra CA, Rivillas CA, Gómez L, Leguizamón JE (1991) Épocas de control químico de la roya del cafeto en Colombia para 1991. Zonas con cosecha importante en ambos semestres del año. Cenicafé Avances Técnicos 156:1-5.

Van der Vossen AM (2001) Coffee breeding practices. In: Clarke RJ, Vitzthum OG (Eds.) Coffee recent developments: Agronomy. London UK. Blackwell. pp. 184-200.

Van der Vossen AM (2005) State of the art of developing durable resistance to biotrophic pathogens in crop plants, such as Coffee Leaf Rust. In: Zambolin L, Zambolin EM, Várzea VM (Eds.) Durable Resistance to Coffee Leaf Rust. Viçosa MG, Brazil. Editora UFV. pp. 1-32.

Van Wyk M, Wingfield BD, Marin M, Wingfield MJ (2010) New Ceratocystis species infecting coffee, cacao, citrus and native trees in Colombia. Fungal Diversity 40:103-117.

Varzea VM, Marques DV (2005) Population variability of Hemileia vastatrix vs. coffee durable resistance. In: Zambolin L, Zambolim EM, Várzea VM (Eds.) Durable Resistance to Coffee Leaf Rust. Viçosa MG, Brazil. Editora UFV. pp. 53-74.

Webster R, Butler E (1967) A morphological and biological concept of the species Ceratocystis fimbriata. Canadian Journal of Botany 45:1457-1468. 